\title{
BOND CHARACTERISTICS AND ROTATIONAL CAPCITY FOR REINFORCED CONCERETE EXTERIOR JOINTS AS AFFECTED BY BONDED PART AND RIB GEOMETRY FOR STEEL REINFORCEMENT BARS
}

\author{
Mahmoud Hussien Ahmed*, Aly Gamal Aly*, Aly Abdel-Zaher \\ Elsayed* and Aly M. Abd-Allah** \\ Civil Eng. Departement, Faculty of Eng., Assiut University, Assiut, Egypt, \\ ${ }^{* *}$ Engineer in the Educational Authority, Sohag, Egypt.
}

(Received May 2, 2011 Accepted June 8, 2011)

The need of high quality of concrete is increased in the recent years. Using steel of high grade and maximize the benefit of using this steel became necessary. So, different ribs are used for steel bars to increase the bond strength between steel reinforcement and concrete. There are different forms of rib geometry of I he deformed bars with either Crescent or Tree profiles for all types of steel in the Egyptian market. Anchorage of reinforcing bars of the beam-column connections is an important design consideration for providing continuity and safety $m$ reinforced concrete structures. This anchorage may be provided by development of straight bars into the exterior joints,

The Egyptian Codes of practice 208 (1995) [1] and 203 (2001) [2] give the values of development length of the deformed reinforcement bars regardless the geometry and the relative area of the ribs.

The main objectives of this research is to study the effect of the rib geometry and the relative rib area on the bond characteristics, the rotational capacity, crack pattern, the mode of failure, the deformation capacity and bond stress of the exterior joints of the structure.

Six specimens of cantilever-to-column connections, which represent exterior joints in structural system, were tested. Type of steel, rib geometry, and bonded part were variables in the tested specimens.

The study concluded that the geometry of the ribs and the bonded part in addition to the steel type have reasonable effect on the bond characteristics of the cantilever-to-column joints and hence on the ultimate load capacity of the joint

\section{INTRODUCTION}

The connections in reality are small areas at which high bending moments may take place. The assumption of fully rigid connection neglects the deformation in the areas of the joints. Thus, no relative rotation will occur between the adjoining members.

Experimental studies show that reinforced concrete and steel beam-column joints are deformed zones. The behavior of the beam to column connection for reinforced concrete is investigated experimentally by many researchers as Ahmed [3], Leon [4] and Springfield [5]. The partial continuity between the beam and the 
column is attributed to the crushing of concrete in compression zones and the cracks occur in the reinforced concrete joint which lead to bar slippage in deterioration of the bond strength between the reinforcing bars and concrete, El-Metwally [6] and Mulas [7]. The connection flexibility has a significant effect on the critical load. The results emphasize that the reduction in the critical load caused by connection flexibility should be taken into consideration.

Biddah and Ghobarah [8"] tested columns designed as compression members with the minimum eccentricity requirements of 0.1 and the anchorage length of $150 \mathrm{~mm}$ for bottom reinforcement were provided according to the ACI code [9] specifications.

Parviz and Ki-Bong Choi [10] concluded that the values of bond stress increase with the increase of the column pressure. Although Untrauer and Henry [11] demonstrated that the increase in bond resistance at different values of slip and at ultimate load under the action of transverse compression. The influence of transverse compression increases with the increase of slip.

Parviz, Choi, Park and Asiani [10 \&12] studied experimentally the effect of confinement reinforcement and compressive strength of concrete on the local bond stress-slip characteristics of deformed bars using specimens simulating the local bond condition of beam reinforcement in beam-column connections. They indicated that confining concrete by transverse reinforcement does not directly influence the local bond behavior of deformed bars in joint conditions where the virtual column bars are sufficient to restrain the widening of bond splitting cracks. They concluded that the ultimate bond strength increases almost proportionally with the square root of the concrete compressive strength.

\section{EXPERIMENTAL WORK}

The investigation of bond characteristics for steel reinforcements with different rib geometry and the rotational capacity of the exterior frame joints in structures are studied in this work. Six specimens of cantilever-to-column connections; which represent exterior joints in structural system; with square cross-section of 30"30 cm were tested under constant static vertical load of 30 tons applied on column and one point of loading at the free end of the cantilever.

Three specimens were reinforced with main steel bars of (BS) and three were reinforced with steel bars of (EZ). The bars were of $18 \mathrm{~mm}$ in diameters placed in tension zone of cantilevers. Each specimen had bonded part of 5, 10,15D and concrete compressive strength of $350 \mathrm{~kg} / \mathrm{cm}^{2}$ for all specimens.

Specimens were tested at age of 28 days under static loading. The column was loaded by constant load of 30 tons and the cantilever was loaded gradually up to failure. Electrical strain gauges for concrete strain, dial gauges for deflection, slip, rotation, slope and the cracks propagation were recorded at the beginning and at the end of each increment of loading as shown in Figs. (1\&2). 


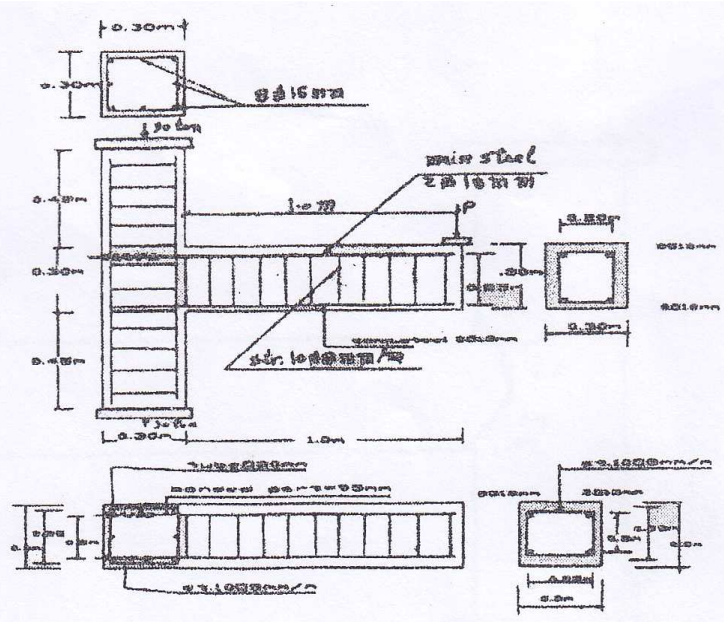

Fig. (1) : Cantilever-to-column connection specimens.

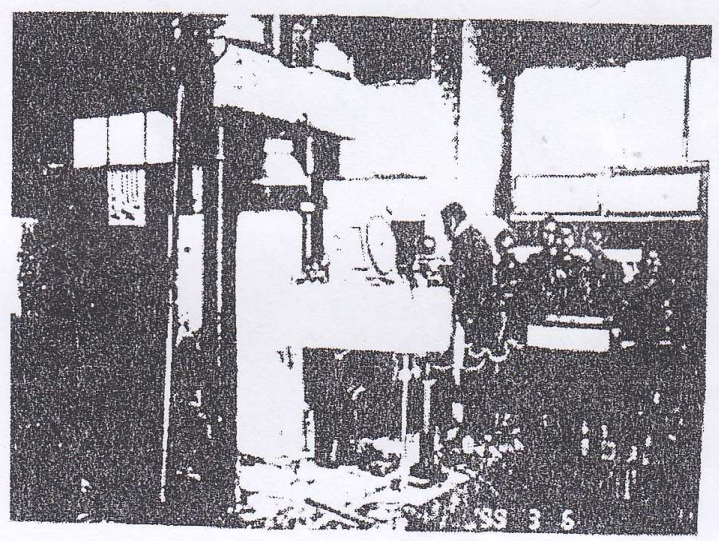

Fig. (2) : Cantilever-to-column connection specimens under test.

The properties of the deformed steel bars used in the tested specimens are given in Table (I).

Table (1); Mechanical and Geometrical Properties of Deformed bars:

\begin{tabular}{|c|c|c|c|c|c|c|c|c|}
\hline Group No. & $\begin{array}{l}D \\
\text { (ni.....) }\end{array}$ & $\begin{array}{l}\text { Specintens } \\
\text { Notition }\end{array}$ & $\begin{array}{c}\text { Profile of } \\
\text { batr }\end{array}$ & $\begin{array}{l}\text { Relative } \\
\text { rib arlal } \\
\left(\omega_{n}, t\right)\end{array}$ & $\begin{array}{l}\text { Yield } \\
\text { sivess } \\
\mathrm{K} / \mathrm{cm} \mathrm{I}^{2}\end{array}$ & $\begin{array}{l}\text { Ultitutale } \\
\text { sticss } \\
\mathrm{K}_{\mathrm{g} / \mathrm{cm}}{ }^{2}\end{array}$ & $\begin{array}{c}\text { Elongation } \\
n / 1\end{array}$ & $\begin{array}{c}\text { Grade of } \\
\text { steel }\end{array}$ \\
\hline $\left.\begin{array}{l}\mathrm{H} \\
\mathrm{G}\end{array}\right\}$ & 18 & $\begin{array}{l}B S \\
E Z\end{array}$ & $\begin{array}{l}\mathrm{T} 2 \\
\mathrm{Cl}\end{array}$ & $\begin{array}{l}0.14 \\
0.06\end{array}$ & $\begin{array}{l}4890 \\
4770\end{array}$ & $\begin{array}{l}7230 \\
7430\end{array}$ & $\begin{array}{c}19.4 \\
20.11\end{array}$ & $\begin{array}{l}40 / 60 \\
40 / 60\end{array}$ \\
\hline
\end{tabular}




\section{TEST RESULTS AND DISCUSSIONS}

The behavior of the tested specimens under loading and the modes of failures were as follows:

The initiation and propagation of the first crack was observed in the critical tension zone at maximum moment. The first crack was vertical tension crack and was at the connection between the column and the cantilever. The height and the width of crack increased with the increase of the load up to the ultimate load and then they increased without increase of the load. The major crack was formed at the same first load and the pattern of cracks is shown in Fig.(3), For the specimen reinforced by steel bars (BS) with bonded part of 15D, other cracks were diagonal tension and formed between the place of critical max. moment and of loading point as shown in Fig. (4).

The width and spacing of cracks were significantly large for a specimen with steel bars (BS). Also, the propagation of the cracks for these specimens was more than those compared for specimens with steel bars (EZ).

The final mode of failure was bond failure for all specimens; except for that with steel bars of (BS) for bonded part of 15D; was bond and flexural failure.

The geometry of the ribs and their spacing can be expressed by the relative rib area. The definition of the relative area of ribs ash is described by Rehm [13] as shown in Fig. (5) as:

$$
\alpha_{s b}=\left(K . F_{R} \cdot \sin \beta_{n}\right) /\left(\pi \cdot D \cdot C_{s}\right)
$$

Where:

$F_{R}=$ area of one transverse rib above the bar core

$\mathrm{Cs}=$ distance between transverse ribs.

$\mathrm{k}=$ number of transverse ribs around the bar perimeter.

$\beta_{n}=$ angle between rib and longitudinal axis of the reinforcement.

$\mathrm{D}=$ nominal diameter of bar

The measured values of deflection, end slip, strain at maximum tension zone, rotation and the slope at the free end of the cantilever-to" column connections versus the applied load are shown in Figs. (6, 7, 8, 9 and 10).

These curves can be divided into three distinct stages as follows:

a- The first stage where there was no cracks in the joint and hence it has a relatively high flexural rigidity

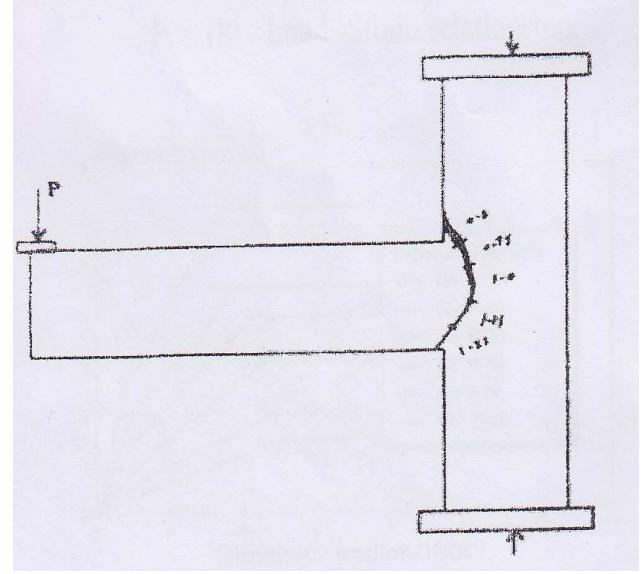




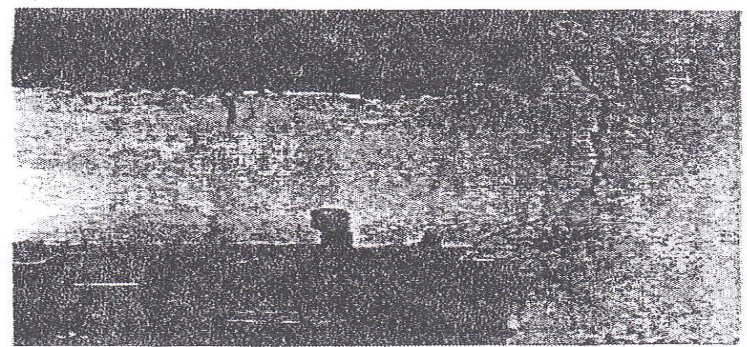

Fig. (3) : Crack shape of specimen (EZ-5D).
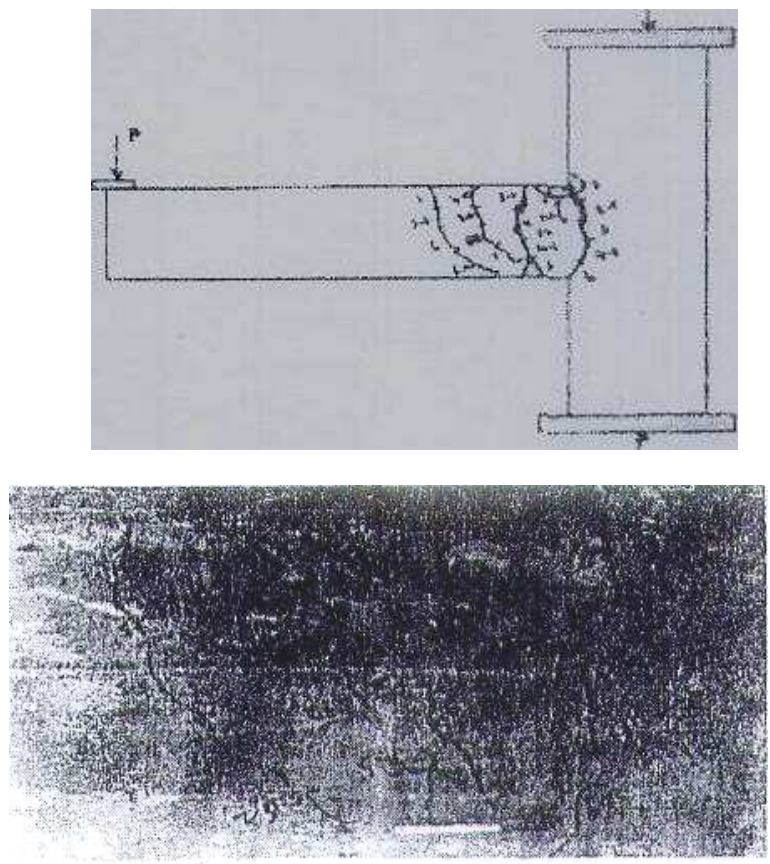

Fig, (4): Crack shape of specimen (BS-15D).
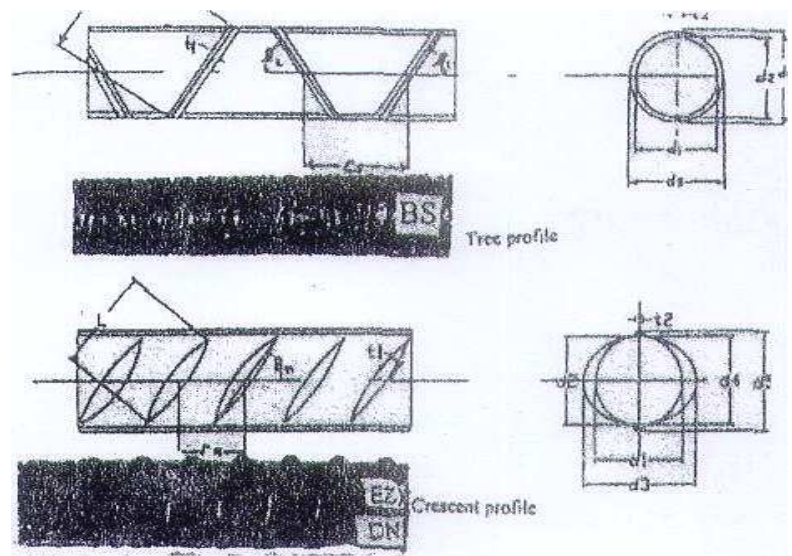

Fig.(5): Properties of the rib geometry of steel bar 


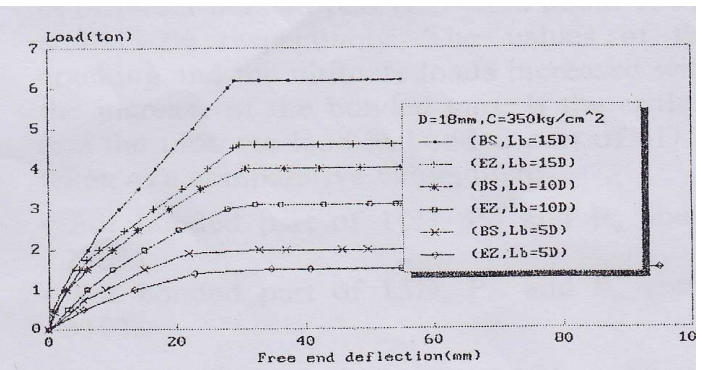

Fig .(6) : Load - deflection relationship.

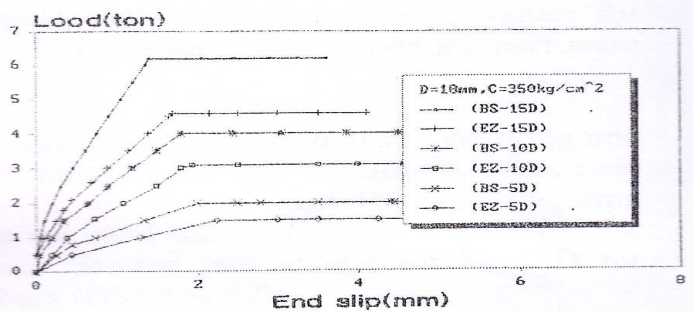

Fig.(7) : Load - end slip relationship.

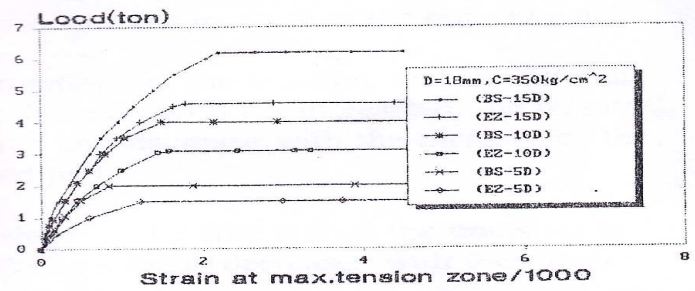

Fig. (8) : Load -Strain relationship.

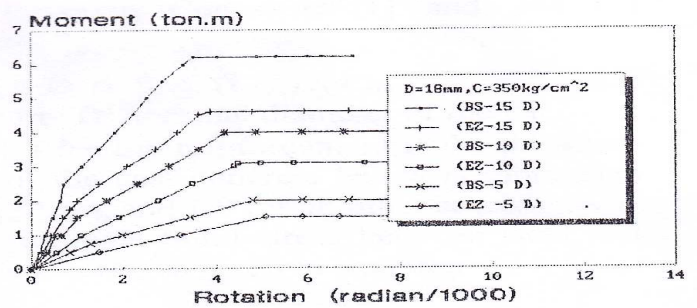

Fig. (9) : Load -rotation relationship.

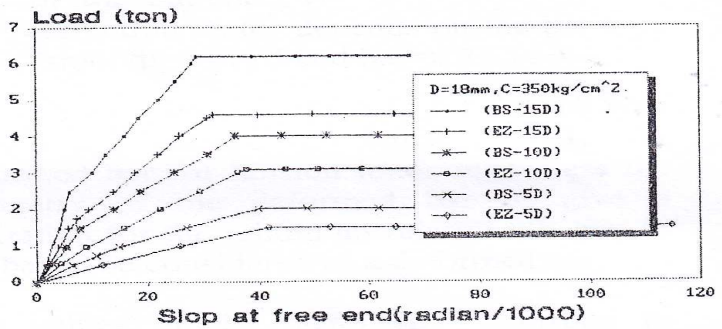

Fig. (10): Load -Slope relationship. 
b- The second stage where the flexural cracks started to form the cracks were propagated and their width and height increased too as the applied load increased.

c- The third stage where the joint of the cantilever-to-column started to fail.

The characteristics of the tested cantilever-to-column at the cracking load and at the ultimate load are given in tables (2 and 3).

\begin{tabular}{|c|c|c|c|c|c|c|c|c|}
\hline $\begin{array}{l}\text { Grou } \\
\text {, No. }\end{array}$ & Series & $\begin{array}{l}\text { Relative tib } \\
\text { Area }\left(\alpha_{\mathrm{rl}}\right)\end{array}$ & $\begin{array}{c}P_{\mathrm{cr}} \\
(\text { (ron) }\end{array}$ & $\begin{array}{l}\text { Detlection } \\
\qquad(\mathrm{m}, \mathrm{m})\end{array}$ & $\begin{array}{l}\text { Slip } \\
\text { (m.m) }\end{array}$ & $\begin{array}{l}\text { Strain } \\
* 10^{3}\end{array}$ & $\begin{array}{c}\text { Rotation } \\
\text { (radian) } \\
{ }^{*} 10^{3}\end{array}$ & $\begin{array}{c}\text { Slope } \\
\text { (radian) }\end{array}$ \\
\hline \multirow[b]{2}{*}{$\mathrm{H}$} & EZ-5D & 0.06 & 0.5 & 5.5 & 0.45 & 0.2 & 15 & 12 \\
\hline & $B S-5 D$ & 0.14 & 0.75 & 5.5 & 0.42 & 0.22 & 13 & 11 \\
\hline \multirow[b]{2}{*}{ G } & EZ-10D & 0.06 & 1.0 & 6 & 0.39 & 0.25 & 11 & 9 \\
\hline & $\mathrm{BS}-10 \mathrm{D}$ & 0.14 & 1.5 & 6 & 0.35 & 0.28 & 10 & 8 \\
\hline \multirow[b]{2}{*}{$F$} & EZ-15D & 0.06 & 1.75 & 6 & 0.32 & 0.33 & 8.5 & 7 \\
\hline & BS-15D & 0.14 & 2.5 & 8 & 0.3 & 0.45 & 7.0 & 6 \\
\hline
\end{tabular}

Table (3): Characteristics of cantilever-to-column connection at ultimate load

\begin{tabular}{|c|c|c|c|c|c|c|c|c|}
\hline $\begin{array}{c}\text { Group } \\
\text { No }\end{array}$ & series & $\begin{array}{c}\text { Relative } \\
\text { rib area } \\
\left(\alpha_{\text {sb })}\right.\end{array}$ & $\begin{array}{c}\text { pu } \\
\text { (ton) }\end{array}$ & $\begin{array}{c}\text { Deflection } \\
\text { (m.m) }\end{array}$ & $\begin{array}{c}\text { Slip } \\
\text { (m.m) }\end{array}$ & $\begin{array}{c}\text { Striatio } \\
\text { n strain } \\
* 103 *\end{array}$ & $\begin{array}{c}\text { Rotatio n } \\
\text { (radion) } \\
* 103 *\end{array}$ & $\begin{array}{c}\text { Slope } \\
\text { (radion) }\end{array}$ \\
\hline \multirow[b]{2}{*}{$\mathrm{H}$} & EZ-iD & 0.06 & 1,5 & 35 & 045 & 1.27 & 5.1 & 42 \\
\hline & BS-5D & 0.14 & 2 & 33 & 0.42 & 0.06 & $4, \mathrm{~g}$ & 40 \\
\hline \multirow[t]{2}{*}{ G } & EZ-10D & 0.06 & 3.1 & 32.5 & 0.33 & 1.61 & 4.5 & $3 \mathrm{ii}$ \\
\hline & RS-IOD & 0.14 & 4 & $3 \mathrm{i}$ & 0.35 & 1.51 & 4.5 & 36 \\
\hline \multirow{2}{*}{$\mathrm{F}$} & RZ-15D & $0-06$ & 4.6 & 30 & 0.32 & 1.78 & $3 . ?$ & 32 \\
\hline & BS-15D & .14 & 6.2 & 29 & 1.4 & 2.21 & 3.5 & 29 \\
\hline
\end{tabular}

The values of the cracking and the ultimate loads from the above tables for steel bar (BS) having relative rib area of $\left(\alpha_{s b}=0.14\right)$ compared to the corresponding values for steel bar (EZ) having relative rib area of $\left(\alpha_{s b}=0.06\right)$ at different bonded part $\left(L_{B}\right)$ were about $150 \%$ and $130 \%$ respectively. The values of the cracking and the ultimate loads increased with the increase of the bonded part. If the critical and the ultimate load at bonded part of 5D is taken as a comparative value, then:

- For bonded part of 10D, $\mathrm{P}_{\mathrm{cr}}$ and $\mathrm{P}_{\mathrm{u}}$ about $200 \%$.

- For bonded part of 15D, $\mathrm{P}_{\mathrm{cr}}$ and $\mathrm{P}_{\mathrm{u}}$ about $310 \%$.

The values of the deflection at the ultimate load for specimens with steel bar (BS) Compared with the corresponding values for steel bars (EZ) for different bonded part were about $95 \%$.

The values of the end slip at the cracking and the ultimate loads for specimens with steel bars (BS) compared with the corresponding values for stee! bars (EZ) were about $92 \%$ for different bonded part except for $\mathrm{L}_{b}=15 \mathrm{D}$ for steel bars (BS) was $82 \%$. 
The values of concrete strains for the tension zone at the cracking and the ultimate loads increase with the increase of the bonded part.

The rotations at the cracking and the ultimate loads decrease with the increase of the relative rib area and decrease with the increase of the bonded part.

The slope at the free end at the cracking and the ultimate loads decreases with the increase of the relative area or for the increase of the bonded part.

The Egyptian Codes 208(1995) [1] and 203(2001)[2] suggest

$$
L_{d}=D \cdot \alpha \cdot \beta \cdot \delta \cdot\left(f_{y} / \gamma_{s}\right) /\left(4 f_{b s}\right)
$$

Where: D; nominal diameter of the bar. ${ }^{\wedge}: 1,4$ for top reinforcement if the thickness of the cast concrete below is more than $30 \mathrm{~cm}$, and 1.0 for all other cases. $\mathrm{f}_{\mathrm{bu}}$ : ultimate bond stress between steel and concrete, as given in equation

$f_{b u}=0 . .3 \sqrt{f c_{u} / \gamma_{c}} \quad \mathrm{~N} / \mathrm{mm}^{2}$

$\alpha$ : Correction factor depends on the type of the bar end- $\beta$ correction factor depends on the bar type (smooth=l or ribbed bar $=0.75$ ).

The values of the correction factor for the type of the bar surface $(\beta)$ equal lo 0.75 for deformed bar for tension loads regardless the geometry of the deformed bar or give a limitation for the minimum relative rib area to the bar to be considered as a deformed bar.

The values of the factor $(\beta)$ according to eq, (2) was calculated for each specimen as shown in table (4).

Table (4): Values of ( $\beta$ ) for cantilever-to-column connection.

\begin{tabular}{|l|l|l|l|}
\hline BONDED PART & 5D & $10 \mathrm{D}$ & $15 \mathrm{D}$ \\
\hline Bar $(\mathrm{BS})$ & 0.152 & 0.152 & 0.147 \\
\hline Bar(EZ) & 0.202 & 0.196 & 0.199 \\
\hline
\end{tabular}

The reduction of the values of the factor $(\beta)$ is due to the increase of the relative rib area $\left(\alpha_{\mathrm{sb}}\right)$ - This reduction causes decrease in length, $\bullet$ width of cracks and increase the stiffness of the cross-section of the cantilever.

The correction factor $(\beta)$ is affected by the following factors:

a- The relative rib area $\left(\alpha_{\mathrm{sb}}\right)$.

b- The bonded part $\left(\mathrm{L}_{\mathrm{d}}\right)$,

c- The steel bar diameter (D).

d- The type of loading (direct or indirect loading).

\section{CONCLUSIONS AND RECOMMENDATIONS}

The following main conclusions and recommendations can be drawn out:

1- The final mode of failure was bond failure for all specimens; except for the specimen with steel bars type (BS) of bonded part 15D;

2- The first cracking load was early observed for cantilever reinforced with bars of small relative rib area and for small bonded part. 
3- The width of cracks was significantly increased with the decrease of both the relative rib area and the bonded part.

4- The values of cracking and ultimate loads increased with the increase of both the relative rib area and the bonded part.

5- The values of the deflection and the slope at the free end increased with the decrease of both the relative rib area and the bonded part.

6- The values of concrete strain, the rotation angle and the rotational capacity decreased with the increase of both the relative rib area and the bonded part.

7- The calculation of the correction factor $(\beta)$ given in equation (2) according to the Egyptian code should be consider the following factors :

a- The relative rib area ( $\alpha \mathrm{sb})$.

b- The bonded part $\left(\mathrm{L}_{\mathrm{b}}\right)$

c- The type of loading (direct or indirect loading).

8- More investigations are needed to study the effect of different parameters of the rib geometry on the characteristics of the cantilever-to-column connections.

\section{REFERENCES}

1. Egyptian Code of Practice for Design and Construction Reinforced Concrete Structures. 208/1995.

2. Egyptian Code of Practice for Design and Construction Reinforced Concrete Structures 203/2001

3. Ahmed, J. D. and Weight K J, " Behavior of Interior Beam to Column Connections under Earthquake type of Loading" ACI, Journal May -June 1985.

4. Leon, T.R-," "Shear Strength and Hysteric Behavior of interior Beam-Column Joints" ACI Structural Joumai, January -February 1990.

5. SPringfield, J., " Semi-Rigid Connections Structural Steel Framing -A Practicing Engineer's View " J - Construct - Steel Research 8-1987, P.P I-1 3.

6. EI-Metwally, S.E - and Chen, W.F-, " Moment-Rotation Modeling of Reinforced Concrete Beam-Column Connection"Cl structure Joumai, July-August 1988-P.P. 384-394

7. Mulas , M.G- and Filippou ,- F-C.," Analytical Procedure In the Sstudy of Seismic Response of Reinforced Concrete Frames" Eng. Struct. Vol. 12, January 1990. PP. $37-48$,

8. Ashraf Biddah and A. Ghobarah "RehabiUtion Strategy for Medium-Rise Buildings" Proceedings of the First Intentional Civil Engineering "Egypt-ChinaCanada" Symposium/Cairo/ Egypt 18-20 December 1997.

9. Building Code Requirements for Reinforced concrete ACI 318-89 and commentary ACI 3 i 8-89, American Concrete Institute, Detroit, Michigan, 1989.

10. Parviz Soroushian and Ki-Bong Choi "Analytical Evaluation of Straight Bar Anchorage Design in Exterior Joints" ACI Structural Journal V. 88, No.2. Mar.Apr.i99 1.

11. Untrauer and Henry. RL, "Influence of Normal Pressure on Bond Strength". ACI Journal May, 1965, PP, 577-585.

12. Parviz. S- Ki-Bong Choi, Gill-Hyun, and Asiani "Bond of Deformed Bars to Concrete Effects of Confinement and Strength of Concrete -ACI materials Journal 
V.8 No.3 May-June 1991,

13. Rehm. G, Eligehausen, R, \& Neubert, B: Eriauterang Dr Bewehrun Gsrich Hinien Rationale for Detaling Provisions of DIN 1045", Deutscher Ausschuss fur Stahlbeion, Heft30, 1979.

\section{خواص التماسك وسعة التشكل والدوران للمفصلات الخارجية من الخرسانة المسلحة متأثرة بطول الرياط وهندسية النتؤات لاسباخ حديد التسليح}

في الآونه الأخيرة زادت الحاجة لاستخدام خرسانة مسلحه عالية المقاومة ولذا أصبح من الضروري استخدام حديد تسليح صلب عالي المقاومة وللاستفادة من المقاومة القصوى لصلب التسليح فإن الأمر يتطلب قوة تماسك لكأك كافية بينة وبين الخرسانة مما يستلزم إحاطة سطح حديد التسليح بنتوءات تكفل نولد قوى التماسك الكافية.

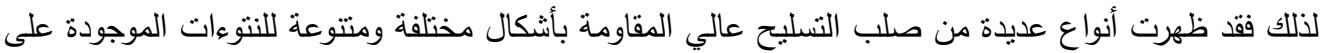
سطح حديد التسليح وأنشهرها النتوءات ذات الثكل الشجري وأخرى ذات الثكل الهلالي وبزوايا ميل مختلفة للنتوء بوهي

ونظرا لاختلاف شكل هندسية النتوءات لهذه الأنواع المختلفة من حديد التسليح فقد ظهرت الحاجة لمعرفة اثز ذلك الاختلاف على مقاومة التماسك بين الحديد والخرسانة. ولقد أجملت المواصفات القياسية المصرية رقم 208 (1995 ) رقم ( ) (203 لسنة (2001) - أثز نوع الحديد في طول الرباط بمعامل بعتمد على نوع الحديد سواء كان أملسا أو ذو نتوءات وأهملت شكل هندسية النتوءات واختلاف المساحة النسبية لهذه النتوءات على طول الرباط لحديد التسليح واثر ذلك على مقاومة التماسك بين الحديد والخرسانة وسعة التشكل الدورانى . لذللك فإن الهدف الرئيسي من هذه الدراسة هو محاولة الوقوف على تأثنير هندسية النتوعات للحديد المشرشر

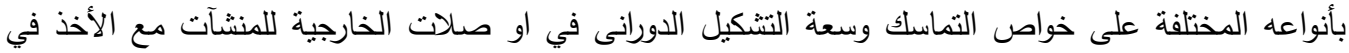
الاعتبار بعض المتغيرات التي تؤثز على هذا السلوك مثل المساحة النسبية للنتوء وطول الرباط الفعال للحديد مع الخرسانة. وقد تمت الدراسة باستخدام عدد (6) عينات تمثل وصلة خارجية مكونة من عمود بكابولى ولقد خلصت الدراسة بضرورة مراعاة تغير المساحة النسبية وهندسية هذه النتوءات على مقاومة التماسك وعلى طول الرباط لحديد التسليح المستخدم في الوصلات الخارجية وضرورة مراجعة المعادلة التي نصت عليها المواصفات المصرية لتضع في اعتبارها العوامل المذكورة. 